\title{
Hadetalens 'grammatik'
}

\author{
Klaus Geyer
}

\begin{abstract}
This article examines constructions for expressing hate speech content as found in user comments on Danish on-line medias' websites. A construction grammar approach is taken because of the flexibility and integrative capacity of this framework in terms of levels of linguistic analysis as well as a form or a function oriented perspective. Out of a whole slew of possible candidates, four constructions are chosen for the analysis as illustrative examples, three of them representing the semasiological perspective (on the levels of graphemics, word formation, and sentential syntax), whereas one construction represents the onomasiological perspective (so called othering, mainly by use of the personal pronouns we vs. they).

The analysis is based on data from the EU-funded project G.O.N.T.A.C.T. (2015-2017), where the University of Southern Denmark contributed as one of the project partners.
\end{abstract}

Nøgleord: hadetale, dansk, konstruktioner, konstruktionsgrammatik, online medier

\section{Introduktion}

Hadetale i online-medier foregår på mange måder, og der bruges vidt forskellige udtryk. Mens enkelte 'grimme' ord relativt nemt kan genkendes (og i givet fald slettes), findes der andre, mere indviklede og indirekte udtryksmåder, som er vanskeligere at afsløre. At ytringskonteksten kan modificere eller tilmed vende rundt på (semantiske) betydninger, så ikke nødvendigvis hvert udtryk, der umiddelbart ligner hadetale, i den konkrete situation fungerer som sådan, gælder selvfølgelig også for disse følsomme elementer. Alligevel prøver jeg på basis af et mindre dataset bestående af læserkommentarer på danske online-mediers websider, at identificere vigtige typer inden for hadetale-udtryk på basis af en konstruktionsgrammatisk tilgang. 
Undersøgelsen er baseret på data fra EU-projektet C.O.N.T.A.G.T. (2015-2017, JUST/2014/RRAC/AG), hvor Syddansk Universitet var en af projektpartnerne, og hvor jeg fik lejlighed til at arbejde sammen med Sharon Millar, Anna Vibeke Lindø og Rasmus Nielsen som en del af den danske projektgruppe.

Artiklen er bygget op som følger: I det følgende afsnit diskuteres det, hvorfor der blev valgt en konstruktionsgrammatisk tilgang, og det skitseres, hvilken slags der viser sig være velegnet såvel for beskrivelsen og analysen i denne artikel som for en intenderet videre- og dyberegående analyse af hadetale-udtryk. I afsnit 3 redegøres der for, hvad der her forstås som hadetale. Databasen for denne delundersøgelse ridses op i afsnit 4. I afsnit 5 analyseres fire påfaldende hadetale-konstruktioner. Udover at være tilsyneladende typiske udtryksmidler giver disse fire udvalgte konstruktioner et indtryk af, hvor vidt det anvendte konstruktionsbegreb kan spænde. Det sidste afsnit 6 indeholder konklusionen. ${ }^{1}$

\section{Grammatik og konstruktioner}

Når der i denne artikel bruges betegnelsen "hadetalens grammatik", impliceres dermed ikke, at hadetale - og her specielt: dansk hadetale især i læserkommentarer på danske online-mediers websider - har en struktur, der indeholder eksklusive grammatiske elementer, som det danske sprog generelt ikke har. Det skal snarere undersøges, hvilke elementer fra det danske sprogs generelle grammatiske repertoire, der udgør de konstruktioner, der typisk bruges for at udtrykke hadetale-indhold og har vist sig at være specielt påfaldende i analysen af materialet. Hadetalens 'grammatik' er altså betegnelsen for de samlede typiske præferencer af udtryksmåder indenfor en sproglig eksistensform (for at bruge en overordnet term for registre, stile og varieteter), som på grund af visse kriterier (se afsnit 3) betegnes som hadetale, lige som andre sproglige eksistensformer som $\mathrm{fx}$ fagsprog, reklamesprog eller sms-sprog har deres 'grammatikker', dvs. deres grammatiske særtræk, uden at konstituere egne sproglige systemer.

Termen 'grammatisk konstruktion' forstås forholdsvist bredt i denne artikel og uden direkte tilknytning til en bestemt fx 'formel' eller 'funktionel'

1. Jeg skylder en ukendt fagfællesbedømmer og mine kollegaer Alexandra Holsting og Uwe Kjær Nissen en stor tak for deres hjælpsomme bemærkninger og for at de omskrev noget som jeg antog at være dansk til rigtig dansk. Alle resterende fejl og fejltagelser er selvfølgelig mit ansvar. 
konstruktionsgrammatisk skole eller teori; dette sker, fordi det er analysen af det sproglige materiale i dets kontekst, der fokuseres på her, og ikke teoridannelsen.

Bergs \& Diewalds (2009: 1f.) generelle tilgang til konstruktioner og til konstruktionsgrammatikken er derfor meget velegnet som udgangspunkt:

Construction grammar is a relatively recent and increasingly popular approach in linguistic theory which postulates that language and knowledge of language consist of conventionalized symbolic form-meaning pairings ('constructions') at all levels of linguistic structure: lexicon, morphology, syntax, possibly even phonology, and discourse/text.

I denne opfattelse af, hvad en konstruktion er, kan små enheder som morfemer og simple ord (simplicia) med deres konventionaliserede, symbolske forbindelse af form og betydning tælles som minimale konstruktioner. En stigende interesse er dog blevet rettet mod de mere komplekse, syntaktiske strukturer, hvor essensen af en grammatisk konstruktion i streng forstand består i dens ikke-kompositionalitet, dvs. at dens betydning ikke bare er resultatet af en simpel addition af de enkelte bestanddeles semantik, men at der ligger en slags ikke-forudsigelig eller konventionaliseret tillægsbetydning i selve konstruktionen, dvs. en slags syntaktisk idiomaticitet; jf. Lakoff (1987: 465), som argumenterer for, "that grammatical constructions in general are holistic, that is, that the meaning of the whole construction is motivated by the meaning of the parts, but is not computable from them."

Konceptet 'syntaktisk idiomaticitet' blev allerede udviklet inden for fraseologien, især i den sovjetiske fraseologi, som reciperedes af bl.a. DDRlingvisterne. Fleischer (1982) introducerer med henvisninger til tidligere sovjetiske fraseologer de såkaldte Phraseoschablonen / fraseoskabeloner, dvs. syntaktiske konstruktioner, som kendetegnes af, at "deren lexikalische Füllung variabel ist, die aber eine Art syntaktische Idiomatizität aufweisen" (Fleischer 1982: 136). Burger taler med henvisning til Häusermann (1977) om Modellbildungen / modeldannelser: "Sie sind nach einem Strukturschema gebildet, dem eine konstante semantische Interpretation zugeordnet ist und dessen autosemantische Komponenten lexikalisch (mehr oder weniger) frei besetzbar sind." (Burger (2007: 45) Den finske fraseolog Hyvärinen (2004) har eksplicit koblet koncepterne fraseoskabelon og (syntaktisk) konstruktion sammen, noget som i øvrigt betegnes som et forskningsdesideratum (fx Hyvärinen 2007: 748) med stort udviklingspotentiale (Sailer 2007: 1069) især indenfor de udvidede korpuslingvistiske muligheder. 
Danske eksempler på fraseoskabeloner eller konstruktioner med syntaktisk idiomaticitet omfatter fx gentagelser af en adjektivform $X$, hvorved en enkel gentagelse af denne adjektivform $X$, forbundet via konjunktionen og, som i (1):

(1) lækker og lækker

betyder 'mere eller mindre $X$ ' eller 'nok ikke rigtigt $X$ '.

Gentages samme adjektivform $X$ derimod to gange (og ytres dermed alt $i$ alt tre gange) med konjunktionen $g$ foran den sidste gentagelse (som i en opremsning), er konstruktionens betydning intensiverende: 'meget $X$ ', jf. (2):

(2) lækker, lækker og lækker²

Det siger sig selv, at disse to betydninger ikke kan findes gennem simpel addition af de enkelte morfemers (eller ords) betydninger, men at der ligger en ekstra betydning i selve den syntaktiske måde at sammenføje morfemerne.

Ifølge Croft (2001) kan en konstruktion også indeholde diskursfunktionelle aspekter som mulige dele af indholdssiden; hans eksempel er sætningskløvninger til fremhævelse. Dette åbner op for den lidt bredere opfattelse af grammatiske konstruktioner, at det ikke kun er den semantiske betydning, som skal være ikke-kompositionel og konventionaliseret, men at også en 'irregulær' pragmatisk betydning, dvs. specielle, konventionaliserede brugsbetingelser, kan konstituere en konstruktion. Et eksempel, som ofte citeres i denne sammenhæng, stammer fra Kay \& Fillmore (1999): What's the fly doing in my soup? (cit. efter Ziem \& Lasch 2013: 13). Dette spørgsmål fra en restaurantgæst til tjeneren, der ud fra sin form er et spørgsmål, fungerer ikke som et funktionelt-pragmatisk spørgsmål, dvs. dets funktion er ikke at udfylde et hul i spørgerens viden, men er udtryk for en uoverensstemmelse i en situation. For at kunne bruge dette spørgsmål adækvat i en situation skal man have viden om brugsbetingelserne, som er en elementær del af den konventionaliserede konstruktionsbetydning. Dette kvalificerer eksempel-spørgsmålet som en konstruktion. Også Lakoff (1987: 467) ind-

2. Sammenlign med disse to eksempler fra nettet, begge to brugerkommentarer. Det første om maden på en restaurant: Lakker, Lekker og Lakker (https:/ /www.tripadvisor.dk/Restaurants-g187824-La_Spezia_Province_of_La_Spezia_Liguria.html), og det andet om en scooter: damn den er jo ALT FOR SYG..! fed farve, og med den motor.!! uff.. lakker lakker. og lakker. x-hoj herfra.. (https://www.scootergalleri.dk/ galleri/155572-yamaha_bwsaerox_solgt_). 
drager pragmatikken, når han konstaterer: "Each construction will be a form-meaning pair (F, M), where $\mathrm{F}$ is a set of conditions on syntactic and phonological form and $\mathrm{M}$ is a set of conditions on meaning and use [min fremhævelse, KG]."

Inden for konstruktionsgrammatikken diskuteres det, om konstruktioner nødvendigvis skal have den slags idiomaticitet, dvs. det uforudsigelige, konventionaliserede, symbolske element, som karakteristikum, eller om alene en tilstrækkelig hyppig brug kan gøre en vis formuleringsmåde til en konstruktion, på trods af at frekvenskriteriet skaber problemer mht. en eksakt afgrænsning. Blandt andre advokerer Goldberg (2006: 5) for dette standpunkt, når hun skriver:

Any linguistic pattern is recognized as a construction as long as some aspect of its form or function is not strictly predictable from its component parts or from other constructions recognized to exist. In addition, patterns are stored as constructions even if they are fully predictable as long as they occur with sufficient frequency.

For ikke at udvande konstruktionsbegrebet og for at undgå problemerne med at skulle afgøre, hvad "sufficent frequency" betyder, følges denne opfattelse dog ikke her, og kriteriet om en nogenlunde uforudsigelig, konventionaliseret, symbolsk relation mellem form og funktion opretholdes.

I det indledende citat af Bergs \& Diewald (2009) blev det adresseret, at konstruktioner kan relatere til sprogets forskellige analyseniveauer. Der hersker nok ingen tvivl om, at syntaksen er konstruktionsgrammatikkens kerne. Morfologiske konstruktioner, især mht. orddannelse, og fraseologiske enheder virker også uproblematiske. Lidt mere indviklede er måske fonologiske konstruktioner - men bemærk fx de syv russiske intonationskonturer, som tilmed kaldes for intonationskonstruktioner - интонационнъее конструкции - på russisk (jf. Gabka 1975: 180-198). Også grafematiske konstruktioner kan med fordel inddrages, hvis man tænker på interpunktionstegn eller den konventionaliserede brug af majuskler for en grafemsekvens i fx chatkommunikation for at indikere dens virtuelt forhøjede lydstyrke.

Ligeledes har især Östman (fx 2005, 2013) fremmet idéen om at konstruktioner ikke stopper ved sætningsgrænsen, men kan omfatte større enheder. I forhold til skriftlige tekster kræver dette en viden om forskellige genrer, og det samme gælder samtaler som 'mundtlige' tekster ("Constructional discourse"). 
Figur 1 sammenfatter diskussionen om, hvad en konstruktion er:

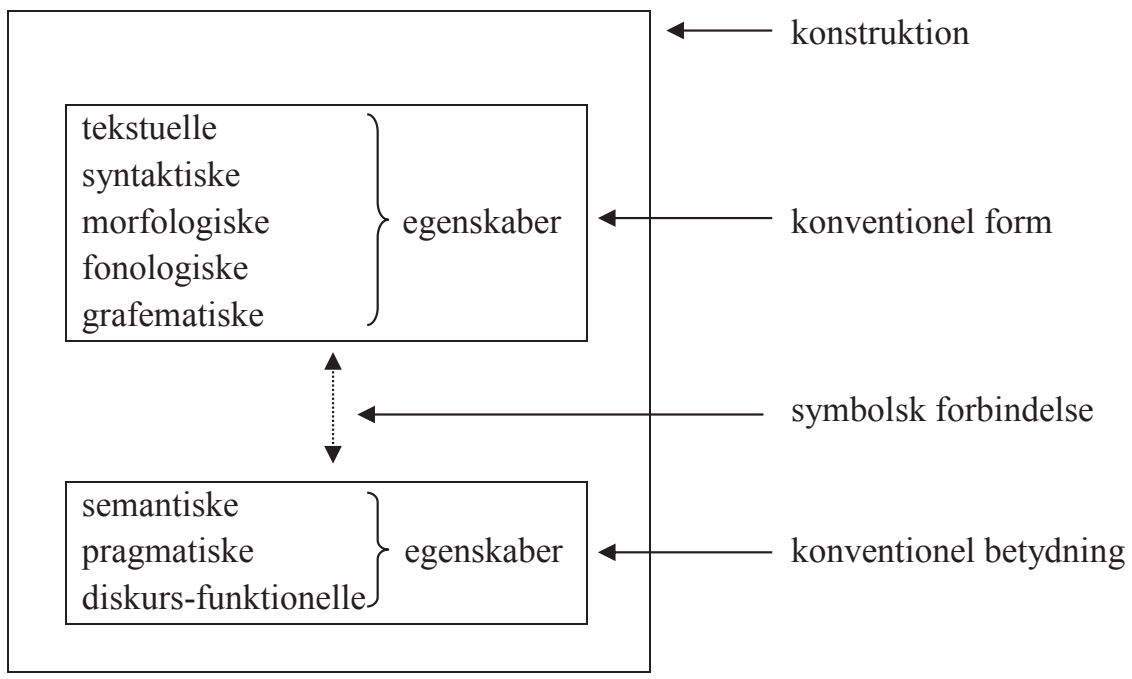

Figur 1: Skema for en konstruktion; udvidet version af Croft (2001: 18) og Ziem \& Lasch (2013: 14).

I den følgende tabel 1, som er inspireret af Ziem \& Lasch (2013: 19), præsenteres danske eksempler på konstruktioner på forskellige niveauer:

\begin{tabular}{|l|l|}
\hline konstruktioner & eksempler \\
\hline grafematiske elementer & STOP NU! \\
\hline bøjningsmorfologi & stor-t \\
\hline afledningsmorfologi & fri-hed \\
\hline simple ord & høne, Marie, og \\
\hline komplekse ord & suppehøne, burhøne, mariehøne; lykkeridder \\
\hline faste flerordsforbindelser & god morgen, heldig kartoffel \\
\hline grammatiske frasemer & det veere sig ... eller \\
\hline idiomer & at se gennem fingre med ngt. \\
\hline fraseoskabeloner & jo X-KOMP, desto Y-KOMP; X og X (adj.); X, X og X (adj.) \\
\hline di-transitiv med delvis åbne slots & ngn. giver ngn. ngt. \\
\hline di-transitiv med åbne slots & ngn. V ngn. ngt. \\
\hline skematiske idiomer & Hvad laver fluen i min suppe? \\
\hline ordsprog (mikro-tekster) & Man skal ikke kaste med sten, når man selv bor i et glashus \\
\hline
\end{tabular}




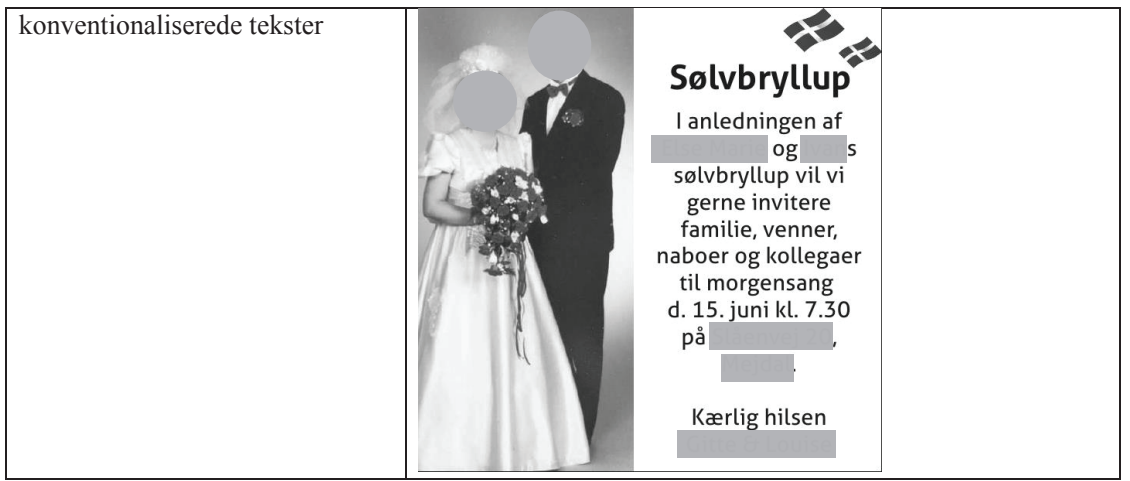

Tabel 1: Eksempler på danske konstruktioner på forskellige sproglige analyseniveauer.

Når der nu opereres med et konstruktionsbegreb, som favner meget bredt, skal der tilføjes to vigtige præciseringer i denne artikel.

Den første præcisering består i at skelne mellem en idiosynkratisk konstruktion som mariehøne og et konstruktionsmønster eller en meta-konstruktion som fx kompositumdannelse, hvor det første led modificerer det andet: suppehøne, perlehøne, burhøne osv. betegner alle sammen forskellige slags høner. Mens den idiosynkratiske konstruktion er fuldstændigt uforudsigelig (som fx betegnelser for 'mariehøne' på andre sprog viser), indeholder et konstruktionsmønster eller en meta-konstruktion en vis forudsigelighed. Ganske vist består den af enkelte elementer, som hver for sig er idiosynkratiske konstruktioner (morfemer, ord); alligevel sammenknyttes disse på en systematisk og forudsigelig måde. Det forhold, at det er kompositummets første led, der modificerer eller bestemmer andet led nærmere betyder, at der er tale om en konstruktion, eftersom modifikationsforholdet er konventionaliseret: en suppehøne er ikke hønesuppe, en perlehøne ikke en høneperle (hvad det så end måtte være) og en burhøne ikke et hønebur.

Som syntaktisk eksempel kan man nævne de tyske transferkonstruktioner med verber som geben 'give', senden 'sende', schenken 'give, forære' eller wegnehmen 'fratage', som udtrykker den semantiske agens-rolle med en nominativ-frase, tema-rollen med akkusativ og recipient-rollen (Hansen \& Heltoft 2011: 131 "receptiv") med dativ. Mønsterkarakteren ses tydeligt ved, at sprogforandringen og sprogindlæringen tenderer mod at tilpasse den leksikalske undtagelse lehren 'undervise', som efter normen konstrueres med to akkusativobjekter, til det gængse mønster for transferkonstruktioner med dativ og akkusativ.

Den anden præcisering giver næsten sig selv, idet konstruktioner per definition har en form- og en indholds- eller funktionsside: Foretages den 
grammatiske beskrivelse eller analyse gennem en tilgang via formsiden, er der tale om semasiologiske konstruktioner, foretages den derimod gennem en tilgang via indholds- eller funktionssiden, er det tale om onomasiologiske konstruktioner. Begge tilgange er nødvendige og supplerer hinanden. Dette princip er velkendt fra grammatikografien, især fra den sprogtypologisk orienterede (jf. fx Croft 1998 og Mosel 2002, med relationer helt tilbage til von der Gabelentz 1901), selvom de fleste grammatiske beskrivelser udelukkende eller overvejende bruger en formorienteret - semasiologisk tilgang. Undersøgelsen af ditransitive konstruktioner (som Goldbergs 1995

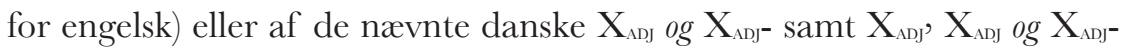
konstruktioner repræsenterer den semasiologiske vinkel; en undersøgelse af possessionskonstruktioner (jf. fx Lehmann 2003 eller Geyer \& Žeimantienė 2010) kan kun forstås som onomasiologisk.

\section{Om hadetale}

Selvom hadetale er et meget aktuelt emne i samfundsdebatten, er der dog ingen konsensus om, hvad hadetale (også: hadtale) - hate speech - præcist betyder. Hadetale er ikke defineret som term indenfor lovgivningen, men bliver snarere brugt som begreb i den politiske diskurs. ${ }^{3}$ Betegnelsen hadetale bruges ikke bare om visse typer ulovlige eller strafbare ytringer; der findes også - og antageligvis i større omfang - ikke-strafbar hadetale. Hvordan beskyttelse mod hadetale og retten til ytringsfrihed skal balanceres, bliver diskuteret mange steder.

Meibauer 2013 giver i en antologi, som samler resultaterne af et interdisciplinært projekt fra universitetet i Mainz, følgende indledende definition: ${ }^{4}$

Unter Hate Speech - hier übersetzt mit 'Hassrede' - wird im Allgemeinen der sprachliche Ausdruck von Hass gegen Personen oder Gruppen verstanden, insbesondere durch die Verwendung von Ausdrücken, die der Herabsetzung und Verunglimpfung von Bevölkerungsgruppen dienen. (Meibauer 2013: 1)

3. Straffelovens $§ 266 \mathrm{~b}$, den såkaldte racismeparagraf, er det sted i dansk lovgivning, hvor fænomenet hadetale adresseres (dog uden at selve ordet bliver brugt).

4. 'Med Hate Speech - her oversat som 'hadetale' - menes i almindelighed det sproglige udtryk for had mod personer eller grupper, især ved at bruge udtryk som nedværdiger eller fornærmer befolkningsgrupper." 
Det diskutable ved denne definition er påstanden om, at hadetale udtrykker had. Det er værd at notere, at kompositummet hadetale selv kan betragtes som en konstruktion, idet det semantisk set ikke bare består af summen af de to komponenter had + tale's betydninger: had er ikke en nødvendig bestanddel af hadetale - men hadetale kan selvfølgelig være hadefuld.

Den Danske ordbog (DDO) angiver betydningen af substantivet had som følger: "1. 'meget stærk følelse af fjendtlighed eller forbitret vrede over for en person som man fx føler sig krænket af'; 1.a 'lidenskabeligt afvisende holdning"”. Betydningen af verbet hade er ifølge DDO: "1. "nære et dybfølt had til'; 1.a 'nære en stærk uvilje mod; ikke kunne udstå"'. Verbets betydning 1.a er altså semantisk blegnet. Det eksempel, DDO giver, er meget velegnet til at klargøre forskellen: Mens Jeg hader madpakker. Jeg hader at købe ind til dem, jeg hader at smore dem og jeg hader at spise dem er helt fint, ville et udtryk som ??had til madpakker være semantisk inkonsistent.

Den definition af hadetale, der ligger til grund for denne artikel, er formuleret af ECRI (Council of Europe, European Commission against Racism and Intolerance) i deres General policy recommendation no. 15 (2016):

Hate speech for the purpose of the Recommendation entails the use of one or more particular forms of expression - namely, the advocacy, promotion or incitement of the denigration, hatred or vilification of a person or group of persons, as well any harassment, insult, negative stereotyping, stigmatization or threat of such person or persons and any justification of all these forms of expression - that is based on a non-exhaustive list of personal characteristics or status that includes "race", colour, language, religion or belief, nationality or national or ethnic origin, as well as descent, age, disability, sex, gender, gender identity and sexual orientation.

Fordelen ved denne definition er at den favner bredt ved at ikke tage hensyn til strafbarheden og ved at nævne både typiske kommunikative handlinger (som fx stigmatisering) og de relevante forhold, som hadetale typisk sigter imod (som fx "race" - bemærk anførselstegnene). Den præsenterer ikke en lukket optælling af de relevante faktorer, men giver plads til udvidelse, i fald der er brug for det. 


\section{Databasen}

Alle eksempler på dansk hadetale, som bliver brugt i denne artikel, stam-

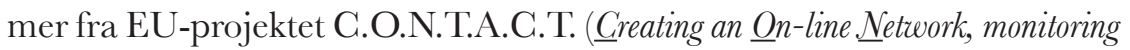
Team and phone App to Counter hate crime Iactics), som blev gennemført i årene 2015-2017. ${ }^{5}$

Dataindsamlingen foregik vha. en søgning i net-baserede medieartikler, som indeholdt visse nøgleord, herunder migrations-relaterede som asylansogere, flygtninge, muslimer, indvandrere ${ }^{6}$ og islam samt gender-relaterede som homoseksuelle, lesbiske, transkonnede, LGBT og homofobi via søgeinstrumentet Newes brief media monitor (http://emm.newsbrief.eu) i to tre-måneders-perioder i 2015 og 2016. Da det ikke var selve medieartiklerne, men brugerkommentarerne, som stod i fokus, udvalgtes kun artikler med mulighed for kommentering, og af disse kun dem, hvor kommentarerne var frit tilgængelige ${ }^{7}$ hvilket ikke er tilfældet for alle websider. Materialet er derfor ikke repræsentativt for brugerkommentarer i de danske medier og tillader ikke statistisk holdbare udsagn. Det er sandsynligt, at artikler, som indeholder de udvalgte nøgleord, også fremkalder undersøgelsesrelevante kommentarer; det betyder dog ikke, at en hvilken som helst artikel om et hvilket som helst emne ikke også kan følges af hadetale-kommentarer, blot at disse er meget sværere at finde end de artikler, der blev søgt efter og fundet med den her anvendte metode.

Da antallet af artikler og i særdeleshed antallet af kommentarer viste sig stadigvæk at være alt for højt til at kunne analyseres med projektets ressourcer, skulle tekstmængden yderligere reduceres, hvilket skete på basis af et kontrolleret tilfældigt valg. Vi endte med en overskuelig, eksemplarisk samling af kommentarer, der alligevel viser nogle tydelige tendenser og giver en idé om det spektrum af konstruktioner, hadetalens 'grammatik' bruger.

Den nedenstående tabel 2 viser det samlede antal artikler for de to tre-måneders-perioder samt antallet af analyserede kommentarer pr. nøgleord. Det bliver tydeligt, at antallet af artikler, som indeholder de migrationsrelaterede nøgleord, er langt højere end antallet af artikler med gender-relaterede nøgleord.

5. Jf. websiden http://reportinghate.eu og Assimakopoulos, Baider \& Millar (2018) for et generelt overblik over projektet; se især Millar et al. (2018) for de danske resultater.

6. Det viste sig at pluralisformerne af personbetegnelser gav mange flere hits end singularisformerne.

7. Dvs. uden betalingsmur og uden brugerregistrering. 


\begin{tabular}{|l|l|l|}
\hline nøgleord & $\begin{array}{l}\text { antal } \\
\text { artikler } \\
\text { i alt }\end{array}$ & $\begin{array}{l}\text { antal } \\
\text { analyserede } \\
\text { kommentarer }\end{array}$ \\
\hline asylansøgere & 5672 & 38 \\
\hline flygtninge & 13975 & 54 \\
\hline muslimer & 2008 & 90 \\
\hline indvandrere & 2124 & 28 \\
\hline islam & 1080 & 65 \\
\hline jøder & 812 & 33 \\
\hline homofobi & 44 & 9 \\
\hline homoseksuelle & 793 & 40 \\
\hline LGBT & 80 & 52 \\
\hline transkønnede & 150 & 15 \\
\hline lesbiske & 265 & 16 \\
\hline transseksuelle & 68 & 18 \\
\hline
\end{tabular}

Tabel 2: Oversigt over antal af artikler og antal af analyserede kommentarer for udvalgte nogleord

\section{Analyser: Hadetalens 'grammatik'}

I dette afsnit præsenteres og analyseres eksempler på fire forskellige hadetalekonstruktioner fra online-kommentarerne: Fra det semasiologiske perspektiv en konstruktion på det grafematiske niveau, en på det morfologiske og en på det sententielle niveau. Derudover belyses fra det onomasiologiske perspektiv en variant af alienerings-konstruktionen (othering). Alle konstruktioner anses som hadetale, da de opfylder kriterierne, som gives i ECRI-definitionen (jf. afsnit 3).

(Ret-)Skrivningen i alle kommentareksempler gengives uden korrekturer.

\subsection{Den grafematiske anforselstegns-konstruktion}

Det første eksempel handler om en ret simpel semasiologisk konstruktion. Anførselstegnenes betydning er mangfoldig (jf. mere udførligt Koller 1975): Ifølge Jacobsen \& Jørgensen (2005) bruges de for at markere citationer, direkte gengivet tale, forskellige forbehold, $\mathrm{fx}$ "at man ikke kan tilslutte sig de holdninger eller fordomme der normalt er knyttet til ordet" (Jacobsen 
\& Jørgensen 2005: 53), omkring nye eller usædvanlige ord samt ordforklaringer (her evt. enkelte anførselstegn).

I eksemplerne (3) til (5) bruges dobbelte anførselstegn, enkelte anførselstegn og anførselstegn + såkaldt omkring personbetegnelserne immigranter og flygtninge for at udtrykke forbehold, nærmere bestemt for at udtrykke en distancering til personbetegnelsernes konventionelle indhold, dvs. for at vise, at ordene her bliver brugt $\mathrm{i}$ en uegentlig mening.

(3) De frivillige som venter paa "imigranter", har de husket baseball bats og knojern?

(4) Go' træning for politiet, for det forsætter jo når 'flygtninge' kommer ud af centre, og ud til den ghetto de bosætter sig i!!

(5) Hullet i statskassen bliver lukket, så snart vi får alle de såkaldte "flygtninge" hjem og fængslet dem, som er på tålt ophold.

Den semasiologiske anførselstegns-konstruktion er et typisk fænomen i det undersøgte materiale; dens funktion i hadetalesammenhæng kan, udover markeringen af uegentlig brug af et ord, beskrives som delegitimiering af de betegnede persongruppers status ( $\mathrm{fx}$ som flygtninge). Den onomasiologiske delegitimeringskonstruktion kan udover anførselstegn udformes som fx kompositadannelser som fupflygtninge, velferdsflygtninge osv. Disse diskuteres dog ikke her.

\subsection{Den morfologiske konstruktion 'person(gruppe)-be- tegnelse + eri'}

Den anden konstruktion, igen semasiologisk, er taget fra orddannelsesmorfologien og består i at aflede et substantiv fra en substantivstamme, som betegner en persongruppe, ved hjælp af suffikset eri. ${ }^{8}$

(6) Man skal være rask for at blive bloddonorer og bøsseri må vel være en sygdom eller hvad

8. Det skal gøres opmærksom på, at suffikset ikke altid optræder i den fulde form eri, men forkortes gennem haplologi alt efter substantivstammens morfologiske endelse: $r y t t e r+$ eri $>$ rytteri $\left({ }^{*}\right.$ ryttereri $)$, bøsse + eri $>$ bøsseri (*bosseer $)$. 
(7) Nogen gange kunne man få den opfattelse, at det er danskerne, der skal lade sig integrere, med al dette 'muslimeri' i medierne

Ifølge artiklen om suffikset -eri i DDO er betydningerne disse:

"1. betegner en gentagen eller vedvarende aktivitet ... med verbum eller substantiv som første led, fx drikkeri, skyderi

1.a bruges til at danne substantiver der betegner en aktivitet som man tager afstand fra, fx luskeri, svineri

1.b betegner resultatet af en aktivitet, især med verbum som første led, fx maleri (! ikke negativ)

2. betegner virksomhed, butik eller afdeling hvor en bestemt aktivitet finder sted også om de personer der udfører aktiviteten, fx bageri, rytteri

3. bruges til at danne substantiver af visse andre substantiver og adjektiver, fx maskineri, lækkeri”

DDO leverer 573 belæg (lemmaer) for tegnkæden *eri, men nogle ord som batteri, deri/heri, beriberi, selleri, difteri, lingeri, hysteri eller periferi skal frasorteres, da de ikke indeholder morfemet eri.

Det viser sig, at langt de fleste eri-dannelser er afledt af verbalstammer $i$ alle tre betydningsvarianter som ordbogsdefinitionen giver. Men når der er tale om afledninger af et substantiv, og især når substantivet betegner en person(gruppe), findes der en tydelig tendens til betydningsvarianten 1.a, jf. ordene checkrytteri, dilettanteri, epigoneri, juleri, juristeri, kammerateri, klovneri, kujoneri, kvaksalveri, paragrafrytteri, pedanteri, pirateri, snobberi, tyveri.

Inventaret kan udvides gennem både fund på KorpusDK, som leverer tyskeri og københavneri, og netfund ${ }^{9}$ som jøderi. Et aktuelt fund fra de sociale medier er humanisteri.

\subsection{Den onomasiologiske alieneringskonstruktion}

Alienering (eller othering) er et udbredt mønster bl.a. i den xenofobiske diskurs (jf. fx Baumgarten 2017). Med alienering tilsigtes det at fremhæve, at nogen ikke tilhører den samme 'vi-gruppe' som en selv (og ens egne). Alienerings-konstruktionen er en onomasiologisk konstruktion, dvs. en konstruktion, som er defineret gennem sin funktion, og den kan antage for-

9. Med søgemaskinen StartPage. 
skellige udtryksformer. I datamaterialet er det især $v i$ vs. de-konstruktionen, der springer i øjnene.

I den almindelige brug er 1. pers. pl. pronominer et middel til dialogorganisation. De betyder 'jeg (= taleren) plus associerede X' og er flydende (jf. Jakobson 1971: shifters) i det henseende, at X alt efter situationen omfatter forskellige personer eller grupper (jf. Geyer 2008: 123f.). I modsætning til dette kendetegnes $v i$ vs. $d e$-konstruktionen ved, at 1. pers. pl. pronominernes funktion er at etablere en in-group i eksplicit modsætning til en out-group; dette gør $v i$ vs. $d e$-konstruktionen til et skematisk idiom.

Eksemplerne (8) og (9) viser særligt tydeligt modsætningen mellem in- og out-group, idet vi bruges med modifikatorer i udvidede pronominalfraser: $\mathrm{Vi}$ Danskere hhv. os etniske majoritetsdanskere. Intentionen at fremhæve modsætningen vises derudover gennem kontrastaccenten, som symboliseres gennem majusklerne $V I$ vs. $D E$ i (8).

(8) efterhånden går alt i dette land ud på at VI Danskere skal indordne os efter muslimerne og deres skide religion, og reglerne skal ændres, så DE kan være her

(9) langt de fleste muslimer herhjemme bare ønsker at leve i deres egen daglige sociale, kulturelle og religiøse "osteklokke". Uden nære relationer til os etniske majoritetsdanskere.

I (10) er det lidt mere implicit, hvem vi omfatter: hele vesten. Eksemplerne (11) og (12) illustrerer, at ikke bare personlige, men også possessive 1. pers. pl. pronominer bidrager til at konstituere alieneringen, muligvis i kombination med adjektivet eget som intensifikator:

(10) Helt ærligt for fredens og demokratiets skyld, burde hele vesten lukke af for muslimer og udvise dem vi har i vores lande

(11) Indvandrerne gør alt hvad de kan, for at vi ikke kan være i vort eget land

(12) Stop nu jeres nasseri for helvede, og lad os danskere være danskere 
I eksempel (12) ses endvidere en variant af $v i$ vs. $d e$-konstruktionen, hvor out-group adresseres gennem en pseudotiltale. ${ }^{10}$

\subsection{Den sententielle adversativkonstruktion Jeg har intet $\operatorname{imod} X, \operatorname{men} . . . '$}

Den sidste konstruktion, der skal behandles, udgøres af et etableret formuleringsmønster, som mange umiddelbart vil kunne genkende. Der findes en vis variabilitet i formuleringerne, som kan ses i eksemplerne (13) til (17). Konstruktionen indledes med et statement om, at emittenten meget generelt accepterer eller tolererer en vis person eller en gruppe af personer eller deres adfærd (har intet imod), som efterfølges af et adversativt men (udeladt i (16)) plus en efterfølgende indskrænkelse af negativ karakter, som fastslår, at emittenten ikke accepterer eller tolererer den person eller gruppe af personer eller dens eller deres adfærd i det konkrete tilfælde, kommentaren (og hele diskursen) relateres til. Det i konteksten eller diskursen relevante hovedudsagn findes snarere i indskrænkelsen, og det stereotypiske indledende statement fungerer mere som en slørende frase.

(13) Jeg har intet imod homoseksuelle, men vil ikke have deres seksualitet stukket op i næsen konstant. De vil accepteres som alm. mennesker, så måske de skulle begynde at opføre dem som alm. mennesker?

(14) Som kristen har jeg intet mod at folk vælger at leve i et homoseksuelt parforhold, făr samme juridiske rettigheder som os andre og kan adoptere, MEN der hvor jeg står af, er når "progressive" præster, prøver at bilde Homoseksuelle ind at Gud anerkender deres livsform

(15) Vi er helt enige, ok homo og lesbisk osv. fint, men hvorfor skal det gøres til et pressionsmiddel og konstant føres frem som om det er den nye religion.

(16) Jeg er ikke homofob, folk kan leve som de ønsker, det jeg brækker mig over er den konstante distanceren sig fra alle os andre heteroseksuelle med alle mulige specielle homo "ting" [...]

10. Det kaldes pseudo-tiltale, fordi det er andre online-kommentatorer, som er de egentlige recipienter, ikke den (konstruerede) gruppe af 'indvandrere'. 
(17) De skal være velkomne til at klæde sig som de vil i deres egen tid, men ligesom at det heller ikke er smart med hverken badedragt, dykkerdragt, motorcykeldragt i læder eller stor balkjole fra forrige århundrede på arbejde i Bilka og Føtex, så er det heller ikke smart med et telt. ${ }^{11}$

Formuleringsmønstret $\mathcal{F}$ g har intet imod $X$, men kvalificeres som konstruktion, fordi det ikke fungerer som et tese-antitese-syntese-diskussionsindlæg, men bruges specielt i hadetale-sammenhæng for at 'hedge' ens udsagn.

\section{Konklusion}

Baseret på et forholdsvis lille dataset af brugerkommentarer i danske onlinemedier har jeg i denne artikel analyseret konstruktioner, der har vist sig at være prominente $\mathrm{i}$ datamaterialet som udtryk for migrations- og gender-relateret hadetale. Der argumenteredes for at følge en bred og brugsbaseret forståelse af konstruktioner, som ikke indskrænker sig til morfosyntaksen, men inddrager flere sproglige analyseniveauer, samt at bruge både en semasiologisk og en onomasiologisk tilgang til den (konstruktions-) grammatiske analyse. At konstruktionsgrammatikken generelt kan drage nytte af at lade sig inspirere af tidligere fraseologiske undersøgelser eller forskningstraditioner, er en yderligere pointe.

Af de fire konstruktioner, der er blevet analyseret, er tre semasiologiske / formorienterede, på det grafematiske, på orddannelses- samt på det sententielle niveau, og en er onomasiologisk / funktionsorienteret: alieneringskonstruktionen.

Denne første undersøgelse har eksemplarisk vist, hvordan hadetale og dens udtryk lingvistisk kan angribes hinsides den individuelle diskursive forekomst. Der hersker dog ingen tvivl om, at der er brug for en meget bredere database samt en dybere analyse af den for at kunne levere mere funderede udsagn om hadetalens grammatik.

\section{Om forfatteren}

Klaus Geyer, dr. phil., Institut for Sprog og Kommunikation, Syddansk Universitet.

11. Dette eksempel handler om, hvorvidt personalet i supermarkeder må bære tørklæde eller burka ("telt") eller ej. 


\section{Litteratur}

Assimakopoulos, S., Baider, F. H. \& Millar, S. (red.) (2018): Online hate speech in the EU: A discourse-analytic perspective. New York, Heidelberg: Springer.

Baumgarten, N. (2017): Othering practice in a right-wing extremist online forum.Language@Internet 14, artikel 1.

Bergs, A. \& Diewald, G. (2009): Contexts and constructions. I: Contexts and constructions. Bergs, A. \& Diewald, G. (red.). Amsterdam, Philadelphia: Benjamins, 1-14.

Burger, H. (2007): Phraseologie: Eine Einfiuhrung am Beispiel des Deutschen. Berlin: Erich Schmidt.

Croft, W. (2001): Radical construction grammar: Syntactic theory in typological perspective. Oxford: Oxford University Press.

Croft, W. (1998): Ein Strukturrahmen für deskriptive Grammatiken: Die Beschreibung sprachlicher Formen. I: Deskriptive Grammatik und allgemeiner Sprachvergleich. Zaefferer, D. (red.). Tübingen: Niemeyer, 17-28.

DDO = Den Danske Ordbog. København: Det Danske Sprog- og Litteraturselskab. http://ordnet.dk/ddo.

Fleischer, W. (1982): Phraseologie der deutschen Gegenwartssprache. Leipzig: Bibliographisches Institut.

Gabelentz, G. von der (1901): Die Sprachwissenschaft: ihre Aufgaben, Methoden und bisherigen Ergebnisse. Leipzig: Tauchnitz.

Gabka, K. (1975): Einfiihrung in das Studium der russischen Sprache. Band 1: Phonetik und Phonologie. Düsseldorf: Brücken-Verlag.

Galberg Jacobsen, H. \& Jørgensen, P. Stray (2005): Håndbog i nudansk (5. udg.). København: Politikens forlag.

Geyer, K. (2008): Personalzeitschriften im deutsch-schwedischen Vergleich: Identifikationsangebote und Wir-Gefühl am Beispiel der Schiffbauindustrie. I: Kontrastive Medienlinguistik. Lüger, H.-H. \& Lenk, H. (red.). Landau: Knecht, 129-146.

Geyer, K. \& Žeimantienė, V. (2010): Zu einer "Grammatik des Deutschen und des Litauischen im Vergleich“: Bestandsaufnahme, Konzeption und Perspektiven. Kalbotyra 62 (3), 22-40.

Goldberg, A. (1995): Constructions: A construction grammar approach to argument structure. Chicago, London: The University of Chicago Press.

Goldberg, A. (2006): Constructions at work: The nature of generalization in language. Oxford: Oxford University Press.

Häusermann, J. (1977): Phraseologie. Hauptprobleme der deutschen Phraseologie auf der Basis sowejetischer Forschung. Tübingen: Niemeyer.

Hyvärinen, I. (2004): Kausative Resultativkonstruktionen als Phraseoscha- 
blonen im Deutschen und im Finnischen. I: Phraseologismen als Gegenstand sprach- und kulturwissenschaftlicher Forschung. Földes, G. \& Wirrer, J. (red.). Baltmannsweiler: Schneider, 135-146.

Hyvärinen, I. (2007): Phraseologie des Finnischen. I: Phraseologie: Ein internationales Handbuch zeitgenössischer Forschung. Burger, H., Dobrovol'skij, D., Kühn, P. \& Norrick, N. R. (red.). Berlin, New York: de Gruyter, 737-752. Jakobson, R. (1971 [1957]): Shifters, verbal categories, and the Russian verb. I: Roman Jakobson. Selected writings. Den Haag, Paris: Mouton, 130-47.

Kay, P. \& Fillmore, G. J. (1999): Grammatical constructions and linguistic generalizations: The 'What's $\mathrm{X}$ doing Y?' construction. Language 75 (1), 1-33.

Koller, W. (1975): Linguistik der Anführungszeichen. I: Impulse: Dank an Gustav Korlén zu seinem 60. Geburtstag. Müssener, H. \& Rossipal, H. (red.). Stockholm: Deutsches Institut der Universität Stockholm, 115-161.

Lakoff, G. (1987): Women, fire and dangerous things. What categories reveal about the mind. Chicago, London: University of Chicago Press.

Lehmann, C. (2003): Possession in Tucatec Maya. Erfurt: Universität Erfurt.

Meibauer, J. (2013): Hassrede - von der Sprache zur Politik. I: Hassrede / Hate Speech. Interdisziplinäre Beiträge zu einer aktuellen Diskussion. Meibauer, J. (red.). Gießen: Gießener Elektronische Bibliothek, 1-16.

Millar, S., Geyer, K., Lindø, A. V. \& Nielsen, R. (2018): Changing participant roles in the expression of hate speech. I: Online hate speech in the EU: A discourse-analytic perspective. Assimakopoulos, S., Baider, F. H. \& Millar, S. (red.). New York, Heidelberg: Springer.

Mosel, U. (2002): Analytic and synthetic language description. I: Linguistik jenseits des Strukturalismus. Ezawa, K., Kürschner, W., Rensch, K. H. \& Ringmacher, M. (red.). Tübingen: Narr, 199-208.

Sailer, M. (2007). Corpus linguistic approaches with German corpora. I: Phraseologie: Ein internationales Handbuch zeitgenössischer Forschung. Burger, H., Dobrovol'skij, D., Kühn, P. \& Norrick, N. R. (red.). Berlin, New York: de Gruyter, 1060-1071.

Ziem, A. \& Lasch, A. (2013): Konstruktionsgrammatik. Konzepte und Grundlagen gebrauchs-basierter Ansätze. Berlin, New York: de Gruyter.

Östmann, J.-O. (2005): Construction discourse: a prolegomenon. I: Construction grammars: Cognitive grounding and theoretical extensions. Östmann, J.-O. \& Fried, M. (red.). Amsterdam, Philadelphia: Benjamins, 121-144. Östmann, J.-O. (2013): Dialects, discourse and construction grammar. I: The Oxford handbook of construction grammar. Hoffmann, T. \& Trousdale, G. (red.). Oxford: Oxford University Press, 476-490. 